\title{
Rainfall and temperatures during the 1991/92 drought in the Kruger National Park
}

\author{
N. ZAMBATIS and H.C. BIGGS
}

Zambatis, N. and H.C. Biggs. 1995. Rainfall and temperatures during the 1991/92 drought in the Kruger National Park. Koedoe 38(1): 1-16. Pretoria. ISSN 0075-6458.

Rainfall and temperatures during the 1991/92 drought, the severest in the recorded history of the Kruger National Park (KNP), are described. Mean total rainfall for the KNP was $235.6 \mathrm{~mm}$ ( $44.1 \%$ of the long-term mean), with a median of $239.9 \mathrm{~mm}$. The number of days on which rain occurred also decreased significantly from a mean annual total of 48.3 to a mean of 24.2 in 1991/92. Daily maximum, minimum and average temperatures for some months increased significantly, as did the number of days within certain maximum temperature range classes.

Keywords: Rainfall, temperatures, drought, Kruger National Park.

N. Zambatis and H.C. Biggs, Department of Research and Development, Kruger National Park, Private Bag X402, Skukuza, 1350 Republic of South Africa.

\section{Introduction}

Over many parts of the country, the rainfall of the 1991/92 climatic year (extending from 1 July to 30 June) is regarded as being the lowest in living memory. At some longterm monitoring stations in the country, 1992 was the driest year on record (Laing 1992).

In this paper, some of the climatic characteristics of the 1991/92 drought are described and compared with long-term means.

Rainfall was investigated in terms of monthly and annual totals, seasonal cumulative rainfall, percentage of long-term mean annual rainfall, the number of rain-days (a 24hour period with a total of $>0.1 \mathrm{~mm}$ of rain) and amount per rain day.

Temperatures were investigated according to mean daily maximum, minimum and average temperatures for each month, as well as the number of days within maxi- mum, minimum and average temperature range classes.

No universally acceptable definition of drought has been developed (Hounam et al. 1975; Wilhite \& Glantz, 1985). This is also reflected in the multitude of definitions of the term. Hounam et al. (1975), for example, list some 60 definitions, while Wilhite et al. (1985) reviewed 150 published definitions of drought, stating that there are four commonly-used definitions of the phenomenon, namely meteorological, agricultural, hydrological, and socio-economic drought. In general terms, they consider drought as a condition relative to some long-term average condition of balance between rainfall and evapotranspiration in a particular area, a condition often perceived as 'normal'.

Ideally, drought should be studied in relation to its duration, intensity, spatial extent, severity and time of occurrence within the annual cycle (Erasmus 1991). A number of 


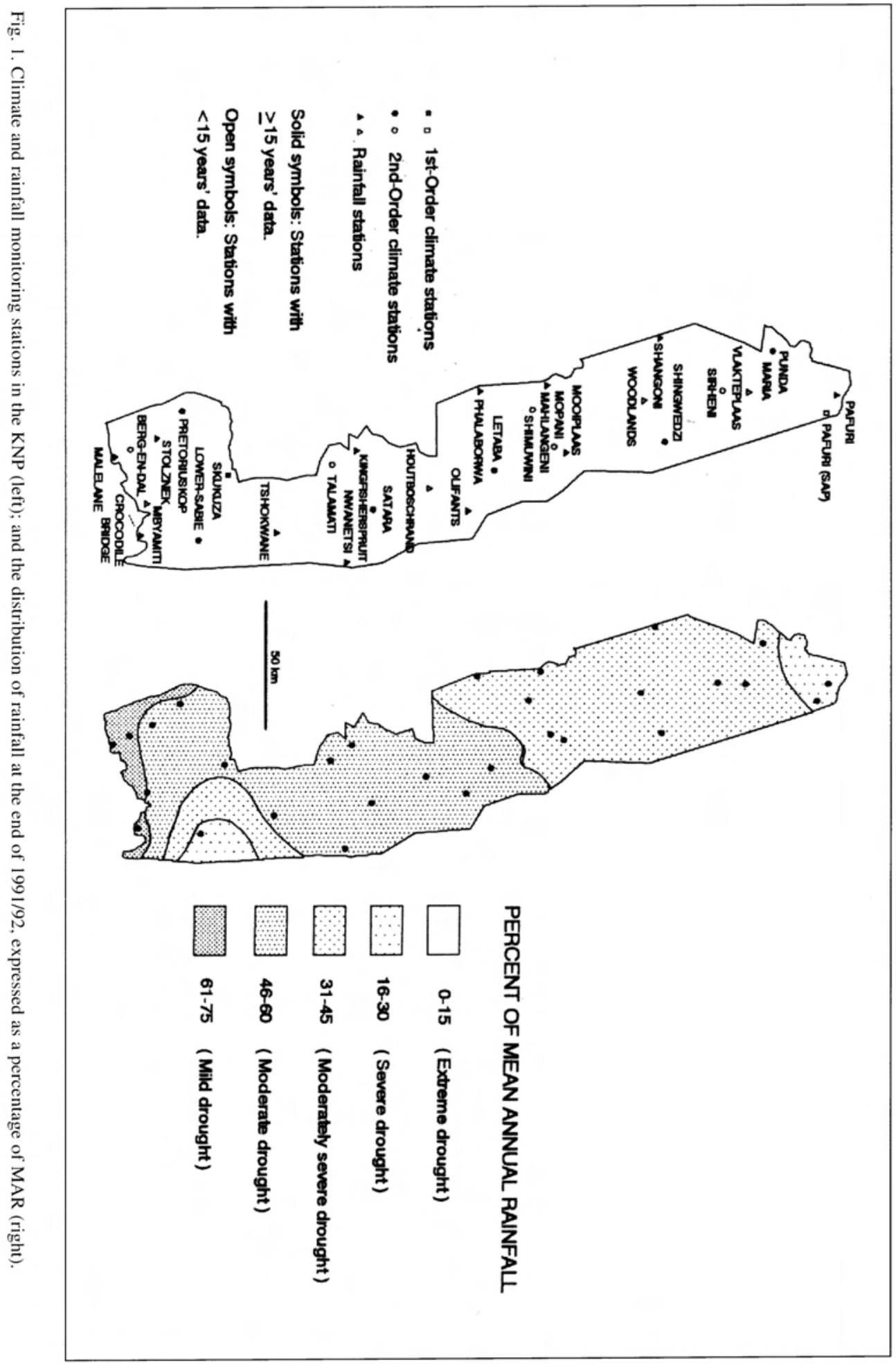


techniques for determining the intensity and severity of drought, as well as evapotranspiration exist. None, however, have thus far been applied to the Kruger National Park.

In this paper, the generally accepted broad categorization of drought is used, namely an area receiving an amount of less than $75 \%$ of the mean annual rainfall (MAR), being regarded as "drought-stricken", while an amount greater than $125 \%$ is regarded as "abundant rainfall" (Weather Bureau 1965; Vogel 1994).

The severity of drought is difficult to determine and is dependent not only on its intensity, duration and geographical extent, but on the demands made by human activities and by the vegetation (Wilhite et al. 1895).

The definition given above, i.e. $<75 \%$ of MAR, does not take into account for example the needs of natural vegetation or planted crops, and can thus be regarded as a meteorological definition.

Many of the definitions of agricultural drought (Hounam et al. 1975) take into account at least some of the components of the water balance equation, namely change in soil water content, rainfall, runoff, deep percolation, evaporation from the soil and transpiration from vegetation (Hillel 1971). They consequently provide a measure of water availability or shortage for the plant and hence a measure of stress, and when related to time, a measure of the duration of this stress and can be determined for relatively short periods of time, e.g. monthly or weekly.

These methods are consequently more appropriate for the assessment of the effects of drought on natural systems than meteorological procedures are. Unfortunately, however, data on some of the inputs required are not easily, cheaply or rapidly obtained, particularly over an extensive area such as the
Kruger National Park and a meteorological definition must perforce be applied.

\section{Methods}

A total of some 52850 daily rainfall records and some 80000 records of daily maximum and similar numbers of daily minimum and average temperature records were used (all stations combined).

Data from 19 rainfall monitoring stations were used to determine long-term means, while data of 26 stations were used to obtain rainfall values for 1991/92. The distribution of these stations is shown in Fig. 1. The following parameters were determined:

- Mean monthly rainfall per station and for the Kruger National Park as a whole.

- Long-term rainfall trends of the KNP, expressed as a percentage of MAR of all stations.

- Cumulative nett rainfall balance (the sum of the difference between long-term MAR and the mean total rainfall for each year in the period concerned; the differences being summed algebraically to give the cumulative total at the end of the period).

- MAR for 1991/92 and for an "average" drought year (excluding 1991/92).

- Number of rain-days for (i) each station during 1991/92; (ii) during an average drought year (excluding 1991/92); and long-term means (including drought years but excluding 1991/92).

- Mean amount per rain-day for the above periods.

All long-term means were determined from data of at least 15 years' duration (Table 2.) Mean number of years of observations is 47.3 ranging from 16 (Stolznek) to 89 (Malelane), with a median of 46 years.

Five climate monitoring stations (Berg-endal, Mopani, Shimuwini, Sirheni and Talamati) and one rainfall monitoring station (Mbyamiti) came into operation during 1991. Only Mopani, Shimuwini, Sirheni and Talamati were, however, operational at 
Table 1

The lowest annual rainfall recorded at 22 stations, and year of occurance

\begin{tabular}{|c|c|c|c|}
\hline Station & $\begin{array}{l}\text { Lowest Annual } \\
\text { Rainfall on Record } \\
\text { (Amount \& Year) }\end{array}$ & Station & $\begin{array}{l}\text { Lowest Annual } \\
\text { Rainfall on Record } \\
\text { (Amount \& Year) }\end{array}$ \\
\hline Crocodile Bridge & $317 \quad 1979 / 80$ & Phalaborwa & $1731991 / 92$ \\
\hline Houtboschrand & $190 \quad 1991 / 92$ & Pretoriuskop & $3821964 / 65$ \\
\hline Kindgisherspruit & $2651982 / 83$ & Punda Maria & $1421982 / 83$ \\
\hline Letaba & 198 1986/87 & Satara & $248 \quad 1946 / 47$ \\
\hline Lower-Sabie & $1391991 / 92$ & Shangoni & $1721963 / 64$ \\
\hline Mahlangeni & $151 \quad 1991 / 92$ & Shingwedzi & $1621986 / 87$ \\
\hline Malelane & $320 \quad 1926 / 27$ & Skukuza & $251 \quad 1991 / 92$ \\
\hline Mooiplaas & $151 \quad 1991 / 92$ & Stolznek & $3621991 / 92$ \\
\hline Nwanetzi & $234 \quad 1972 / 73$ & Tshokwane & $2561991 / 92$ \\
\hline Olifants & $1681991 / 92$ & Vlakteplaas & $2421991 / 92$ \\
\hline Pafuri & a $98 \quad 1982 / 83$ & Woodlands & $215 \quad 1983 / 84$ \\
\hline
\end{tabular}

a Lowest annual rainfall ever recorded in the KNP.

the start of the 1991/92 climatic year and their data were included in the analyses of the year's rainfall and temperatures.

Temperature characteristics were investigated by comparing long-term means with values for 1991/92, the following parameters being determined:

- Mean daily maximum, minimum and average temperatures (average temperature $=($ maximum + minimum) $/ 2$ )

- Number of days with maximum, minimum and average temperatures within certain temperature range classes.

Missing temperature data were treated according to the rules of World Meteor ological Organization (1983) and the SA Weather Bureau. According to these rules, if data for 10 days or more (or four consecutive days or more) in a month are missing or the data is unreliable, then means and extremes for the month cannot be determined. The same rules were applied in determining the number of days within a specific temperature range class.
The application of these rules resulted in a considerable number of months in the databases of most stations being excluded from the analyses. This was particularly the case with the data of earlier years, when checking of data at a local level and guidance of observers on correct procedures was not a routine practice.

In determining long-term monthly means, therefore, unusable data was "filtered out" and means for a specific month were determined as follows (daily maximum temperature is used as an example).

For a specific month,

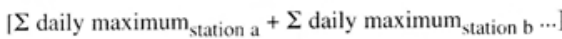

$\left[\Sigma\right.$ observations station a $+\Sigma$ observations $\left._{\text {station }} \mathrm{b} \ldots\right]$

By using monthly data in this manner, a considerably greater percentage of the data base could be used than would have been possible if only those years with no or very few missing records were chosen and means then determined: A relatively very small proportion of all years is entirely complete, 


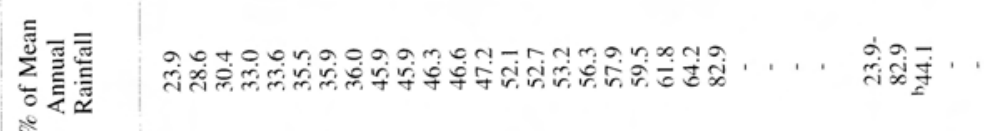

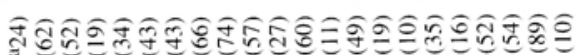

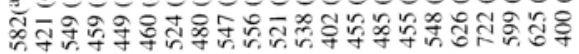

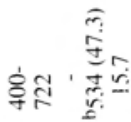

\section{onrtongong tomroponge-n to 000} बî日

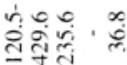

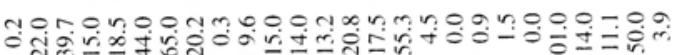

कำำำ

ग

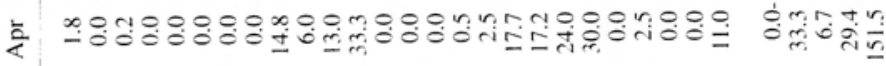

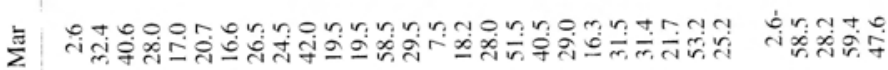

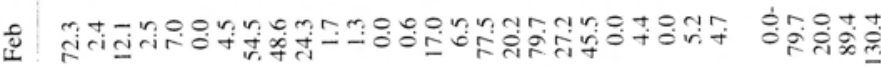

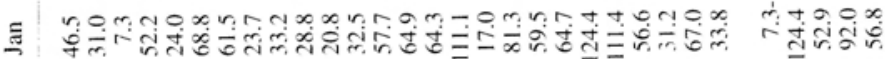

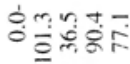

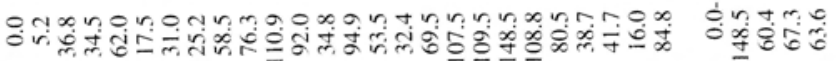

о

ڤ̆

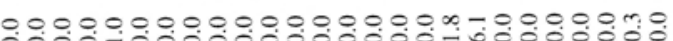

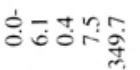

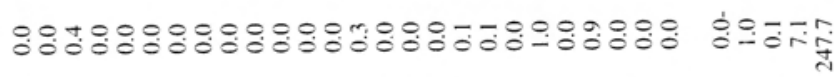

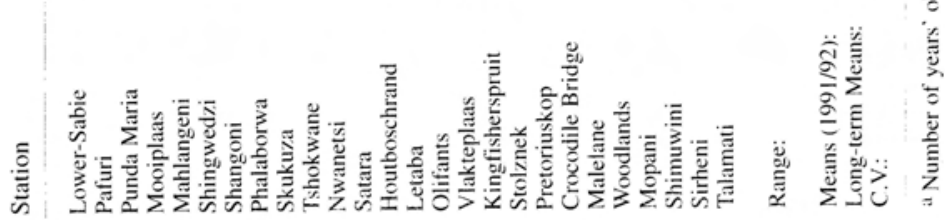




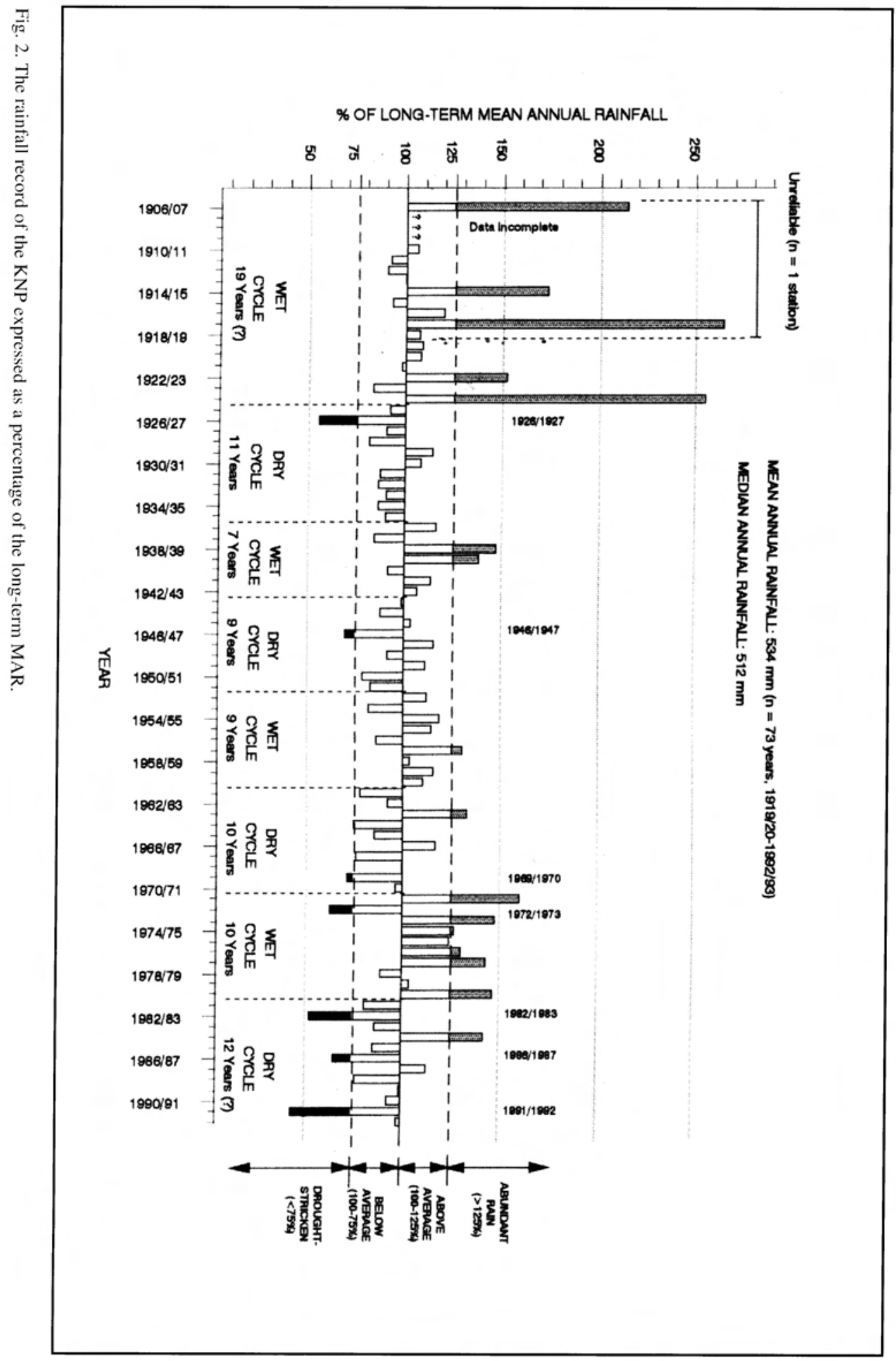


resulting in the entire year as a whole having to be discarded and together with it, months with no errors or omissions. Long-term means obtained in this manner were compared with those given in Weather 'Bureau (1988) for older stations (Letaba, Pretoriuskop, Punda Maria, Satara, Shingwedzi and Skukuza) and covering a mean period of 31.5 years up to 1984 . Very small and insignificant differences were found. In this investigation, data of these stations extends over an average period of 30 years and three months.

Due to missing or unusable data, however, this period decreases to an average of 20 years and seven months. The highest quality of data is that of Skukuza, with 30 years and 10 months' usable data.

Statistical significance of differences between means was determined using a twosample analysis procedure (at 0.05); while that of yearly means was tested using a twoway analysis of variance to block for the effect of month (at 0.05) as provided in the Statgraphics Version 6.0 computer software programme (Manugistics 1993). The distribution of rainfall classes (Fig. 2) and the percentage area covered by each class was determined by interpolation using GIS procedures (Spans 5.3 computer software programme) using non-linear interpolation and also extending outside the convex hull.

\section{Results and discussion}

A situation similar to that described by Laing (1992) prevailed in the Kruger National Park. Ten of the 22 monitoring stations with records of ten years or longer recorded the lowest totals in their existence. At 12 stations, however, drier years have been recorded before 1991/92. Apart from Woodlands, the latter stations have records extending over at least 27 years, while the records of four range between 40 and 60 years (Tables 1 and 2). The lowest rainfall recorded by each of 22 stations in the KNP is given in Table 1. The lowest annual rainfall ever recorded in the KNP was $98.0 \mathrm{~mm}$ (23.3\% of long-term MAR), recorded at Pafuri during the 1982/83 drought.

Monthly totals recorded at 22 monitoring stations during 1991/92, MAR, and percentage of MAR received in 1991/92 is given in Table 2 . The greatest range in monthly totals occurred in the wettest months, namely December, January, and February. Although rain in the long term has been recorded during every month, a monthly total of $0.0 \mathrm{~mm}$ was recorded at at least one station during all months in 1991/92, except in January and March, the former normally being the wettest month. The mean total for the year was $235.6 \mathrm{~mm}$ (median $239.0 \mathrm{~mm}$ ), a mere $44.1 \%$ of the long-term mean of $534 \mathrm{~mm}$.

Great variation between stations for most months is evident, with the coefficient of variation (C.V.) ranging from 349.7 in August to 47.6 in March. The C.V. of the year's MAR was also more than twice as great as that of the long-term MAR, namely 36.8 and 15.7 respectively. The greatest difference between the long-term mean monthly rainfall and the total rainfall for a specific month during 1991/92 occurred in February, the average difference being $69.4 \mathrm{~mm}$.

All but one station received less than $75 \%$ of the long-term MAR - the only exception being Woodlands with $89.2 \%$ (Table 2). This however, together with that of Vlakteplaas and Houtboschrand are probably overestimates due to the relatively short periods on which the long-term means for these stations are based. Gertenbach (1980) states that acceptable averages can only be determined with approximately 40 years' data, i.e. a period representing two wet and 
two dry cycles. Lynch \& Dent (1990) undertook a regional delimitation of the number of years of records required in order to produce an estimate of MAR which is within $10 \%$ of the long-term mean for $90 \%$ of the time. According to this delimitation, the entire KNP falls within a 15 year zone. It is thus assumed that the MAR of Woodlands and Vlakteplaas is considerably higher estimated at approximately $450 \mathrm{~mm}$ and 500 $\mathrm{mm}$ respectively. In the case of Houtboschrand, this differs little from the 33-year mean of $407.8 \mathrm{~mm}$ recorded at the Klaserie Private Nature Reserve headquarters, some $50 \mathrm{~km}$ west of Houtboschrand (Zambatis 1994). As with all the other stations in the KNP then, Woodlands in all probability received considerably less than the $75 \%$ threshold during 1991/92.

If the drought categories shown in Fig. 2 were to be arbitrarily extended to below the $75 \%$ level, then in a meteorological context, $75-61 \%$ are arbitrarily described here as a "mild drought"; 60-46\% as "moderate drought"; $45-31 \%$ as "moderately severe drought"; $30-16 \%$ as "severe drought"; and $15-0 \%$ as "extremely severe drought". It is clearly evident from Fig. 2 that according to these criteria, the KNP in 1991/92 as a whole received the lowest rainfall on record.

Lower-Sabie and Pafuri received $<30 \%$ of their long-term MAR during 1991/92; Punda Maria, Mooiplaas, Mahlangeni, Shingwedzi, Shangoni and Phalaborwa 3040\%; Skukuza, Tshokwane, Nwanetsi and Satara 40-50\%; Olifants, Letaba, Kingfisherspruit, Stolznek and Pretoriuskop 50$60 \%$; and Crocodile Bridge and Malelane $60-70 \%$

According to the above criteria, severe drought conditions occurred over $6.4 \%$ of the KNP (Pafuri and Lower-Sabie regions); with moderately severe drought conditions extending over $47.5 \%$, moderate drought over $42.9 \%$ and mild drought over $3.2 \%$ of the KNP. Severe to moderately severe drought thus occurred over $54 \%$ of the park. The distribution of these categories is shown in Fig. 1.

A relatively steep east-to-west rainfall gradient is evident in the southern part of the KNP during 1991/92, with a more gentle gradient in a north-south direction. This pattern broadly corresponds with the topography of the park, the highest part being in the south-western corner.

In ecological terms, it appears that an amount of less than some $80 \%$ of MAR results in discernible limitations on grass production. Furthermore, as total rainfall decreases, the severity appears to increase sharply, rather than linearly. The descriptive terms used above consequently belie the fact that the 1991/92 drought had a severe to very severe impact on a diversity of biological organisms over most of the KNP.

In comparing the 1991/92 drought with that of $1982 / 83$, it is essential to bear in mind some important differences between these two years and to take into consideration the events of the periods preceding these droughts. The 1982/83 drought was preceded by a 10-year wet cycle, seven years of which received above-average rainfall (Fig. 2.). The overall effect during this period (including 1981/82, the commencement of the current dry cycle, but excluding the 1982/83 drought) was a cumulative nett rainfall balance of $834.7 \mathrm{~mm}$ above the longterm MAR at the commencement of the 1982/83 drought, decreasing to $583.7 \mathrm{~mm}$ by the end of the 1982/83 climatic year.

In contrast, the 1991/92 drought was preceded by two other droughts, namely those of $1986 / 87$ and 1982/83, the latter also being the severest prior to 1991/92. The latter drought occurred during a currently dry cycle and was preceded by seven years with 

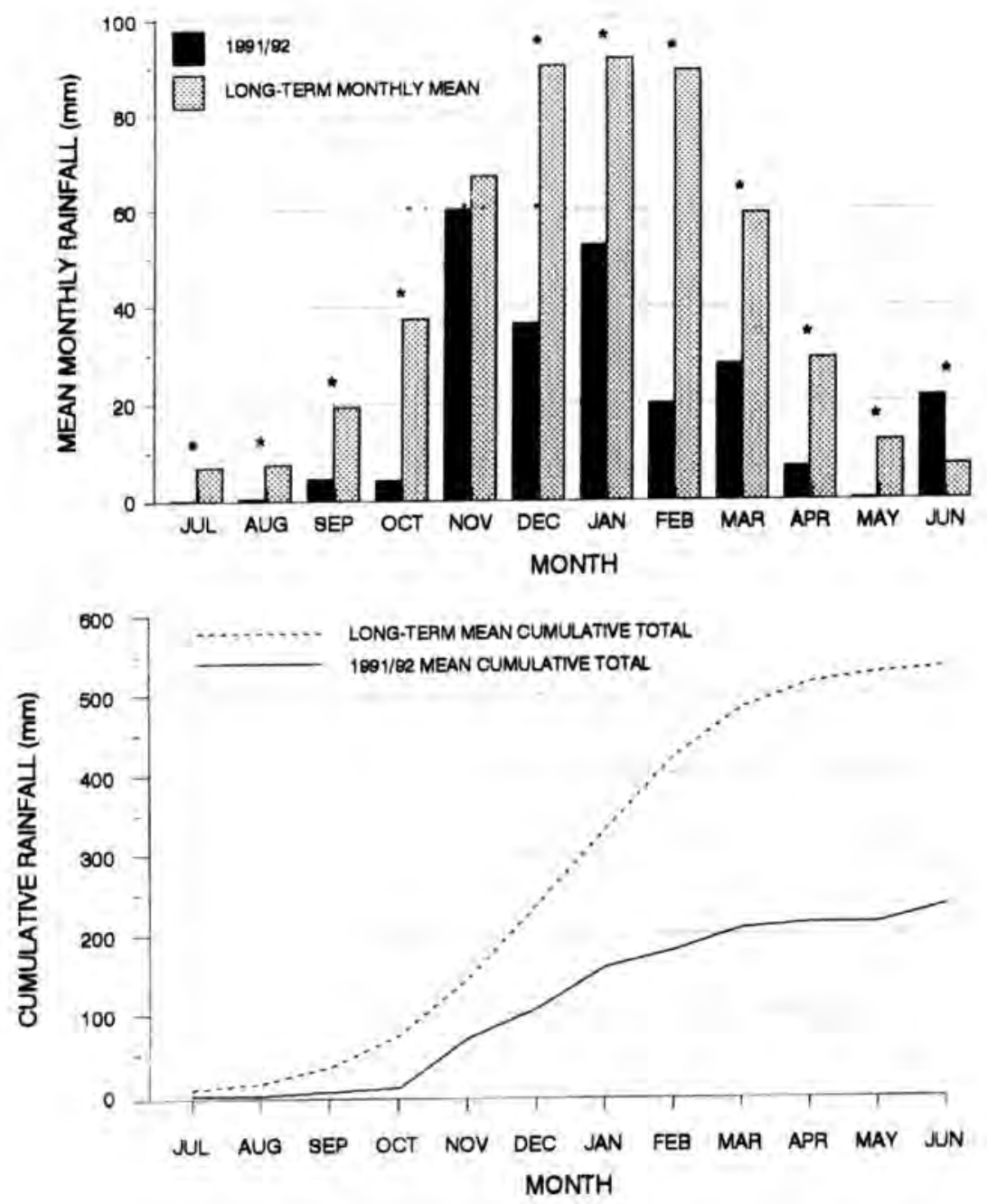

Fig, 3. Top: Mean monthly rainfall for 1991/92, and long-term mean monthly rainfall. Statistically significant differences are marked with an asterisk. Bottom: Cumulative rainfall during 1991/92 compared with the long-term mean.

below-average rainfall, resulting in a cumulative rainfall deficit of $257.7 \mathrm{~mm}$ at the commencement of the 1991/92 climatic year. By the end of the year, this deficit increased to $556.1 \mathrm{~mm}$. These events have had far-reaching consequences on various components of the KNP ecosystem, as reflected in a special report on this topic
(Venter \&Mills in prep.).

Several other noteworthy phenomena are also apparent from Fig. 2. Wet and dry cycles on average appear to be of ten years' duration (Gertenbach 1980). However, it is interesting to note that the initial (recorded) wet cycle (1906/07 to $1924 / 25)$ was 


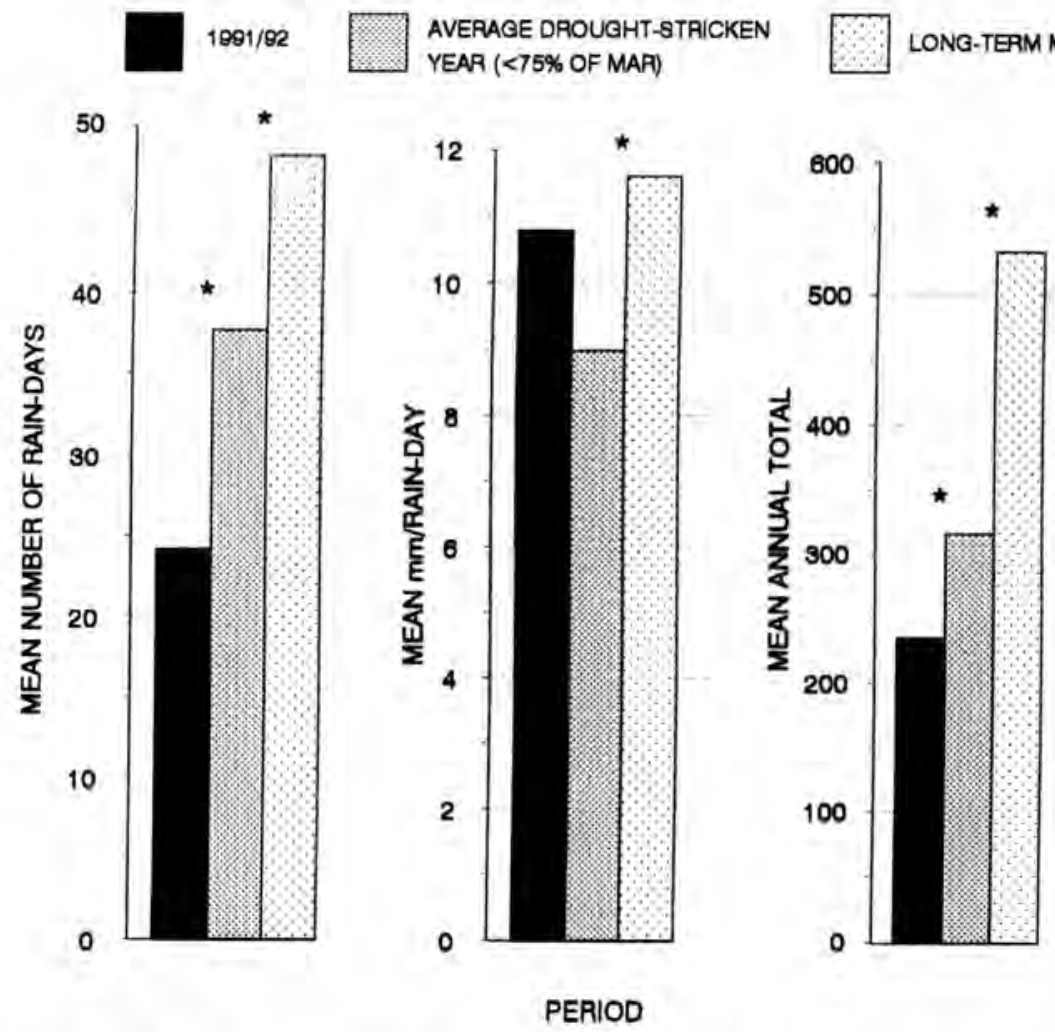

Fig. 4. Mean number of rain-days, mm per rain-day and MAR during (i) 1991/92; (ii) an average drought-stricken year (excluding 1991/92); and (iii); the long-term means for each category.

abnormally long (at least 19 years), as is the current dry cycle, currently 12 years long (end of the 1992/93 climatic year).

Pienaar (1985) mentions the possibility of an 80-100 year cycle with extremes in rainfall, i.e abnormally high and low rainfall. Referring to the dendrochronological work undertaken by Hall on a yellowwood (Podocarpus falcatus) from the Karkloof Forest of Natal, Pienaar shows that during the preceding 645 years, wet and dry cycles of 80 years' duration occurred four times, and cycles of 100-110 years three times. The rainfall records of the KNP appear to confirm the opinion of Pienaar (1985) and the dendrochronology of Hall, namely the occurrence of cycles of approximately 80100 years.

During the current dry cycle, the magnitude of the 1982/83 and 1991/92 droughts, and the frequencies of droughts during this cycle are clearly greater than during any other. Since 1971/72, the frequency of years with abundant rain is greater than at any other period this century, including the period before 1925. These events may be a reflection of changes in the southern African climate (Tyson 1986). 
It was initially suspected that the abnormally high rainfall records of the KNP before 1925 were incorrect. Records of the few stations that were recording rainfall during this period and which were near the KNP were consequently inspected to determine if these years were, in fact, abnormally wet. During 1924/25, $1162 \mathrm{~mm}$ were recorded at Champagne, $1357 \mathrm{~mm}$ at Bushbuckridge, and $1255 \mathrm{~mm}$ at Malelane town. In the KNP, $1711 \mathrm{~mm}$ were recorded at Punda Maria and 1115 at Skukuza (Weather Bureau records). In the annual reports of that period, Col. J. Stevenson-Hamilton reports that "There was a heavy rainfall and floods in the early months of 1906" and "...heavy rainfall and excessive floods during the first three months of 1907".

The failure of the 1991/92 rains is illustrated in Fig. 3. During all months, except June 1992, the mean total rainfall for each month, in most cases, was far below that of the long-term monthly mean. Highly significant differences $(\mathrm{P}<0.0001)$ between long-term monthly means and the monthly means of most months in 1991/92, except for July ( $P$ $=0.011$ ) were found.

Comparing cumulative totals (Fig. 3), the difference between 1991/92 and long-term MAR steadily increased until a final deficit of $298.4 \mathrm{~mm}$ was recorded by the end of the climatic year. This would have been even higher, had it not been for a seemingly freak amount of $21.7 \mathrm{~mm}$ (vs. $7.2 \mathrm{~mm}$ ) which fell in June, with Woodlands receiving 101.0 $\mathrm{mm}$ during this month. This was also the only month during which the mean monthly total was greater than the long-term monthly mean (Table 2 and Fig. 3).

The mean total number of rain-days for all stations in 1991/92 was 24.2 (Fig. 4). The median was 21 and ranged from 10 at Olifants to 69 at Pretoriouskop. There was a decline of $35.8 \%$ from an average drought- stricken year with a total of 37.7 rain-days. When compared to the long-term overall mean of 48.3 days, the decline was significant $-49.9 \%$ - in the $1991 / 92$ season.

In contrast, the average amount per rain-day in 1991/92 was slightly higher than that of an average drought, namely $10.8 \mathrm{~mm}$ vs. $9.0 \mathrm{~mm}$, and only $0.8 \mathrm{~mm}$ less than the longterm average of $11.6 \mathrm{~mm}$. These differences were not statistically significant.

In terms of total rainfall, 1991/92 on average received $72.5 \mathrm{~mm}$ less than the average drought year, but $290 \mathrm{~mm}$ less than the longterm of $534 \mathrm{~mm}$, and $276.4 \mathrm{~mm}$ less than the median of $512 \mathrm{~mm}$. It is thus clear from Fig. 4 that although the differences in the mean amount of rainfall per rain-day are statistically insignificantly small, the number of days on which rain occurred in 1991/92 were very significantly less less than those of the long-term mean.

When referring to air temperature, "hotness" or "coldness" can be expressed according to different criteria, for example the extreme highest or lowest temperatures, the averages of daily maximum and minimum temperatures, or the number of days with maximum or minimum temperatures within a certain range class. Extreme temperatures provide a measure of intensity, whereas the number of days within a certain temperature range being a measure of frequency, provides a measure of the persistence of these temperatures. The latter thus presents a better overall indication of hotness or coldness than extreme temperatures would do. Nevertheless, when compared with longterm means, maximum and minimum temperatures provide some indication of deviation from these means, as well as the intensity of high and low temperatures.

Except for September, (which had a practically normal mean daily maximum), daily maximum temperatures during all months in 


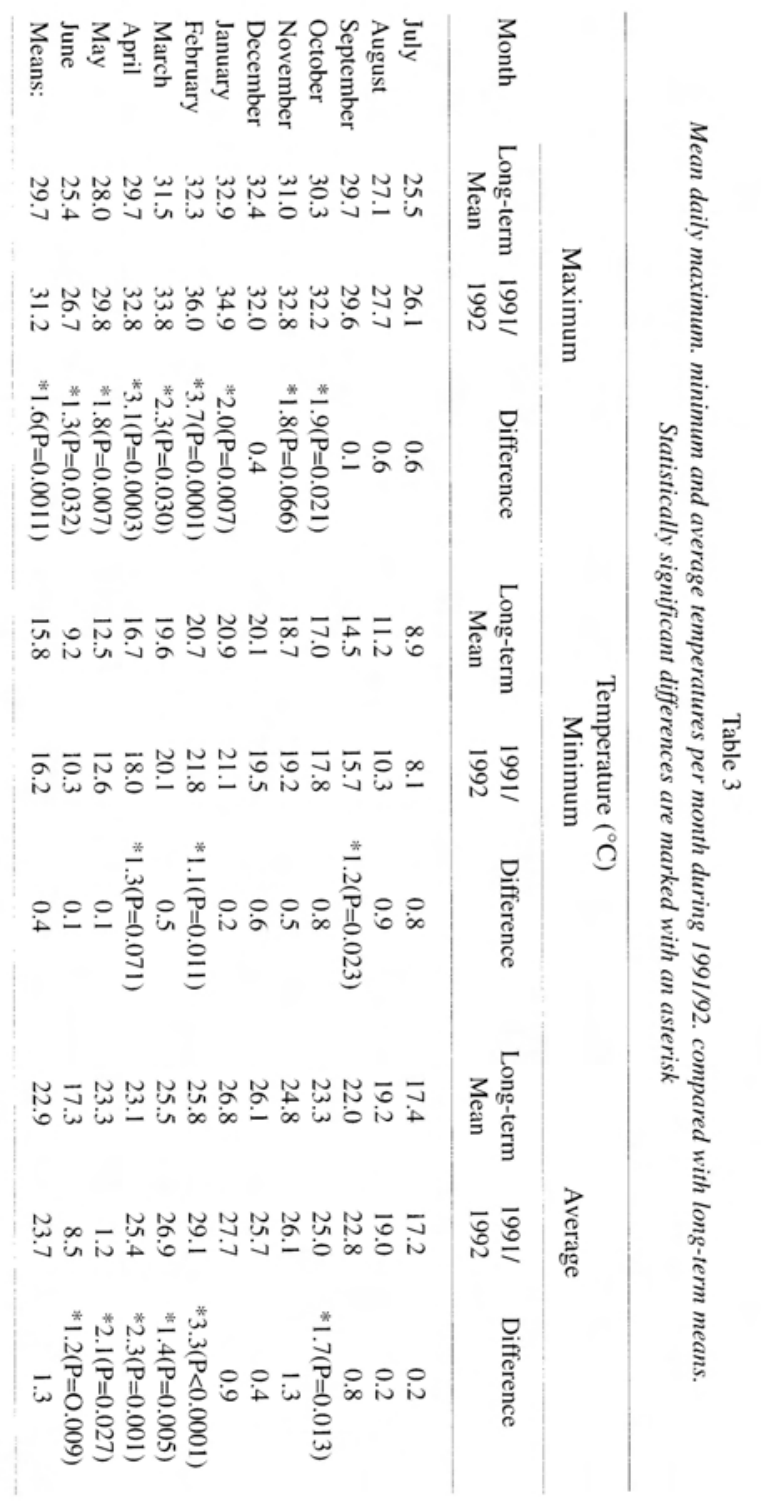


Table 4

New maximum temperature records established on 26 February 1992, and previous records

\begin{tabular}{|c|c|c|c|}
\hline \multirow{2}{*}{$\begin{array}{l}\text { Station } \\
\text { Berg-en-dal }\end{array}$} & \multirow{2}{*}{$\begin{array}{l}\text { New maximum - } \\
\text { temperature records } \\
\text { (26 February 1992) } \\
45.0\end{array}$} & \multicolumn{2}{|c|}{$\begin{array}{c}\text { Previous highest } \\
\text { maximums and } \\
\text { dates }\end{array}$} \\
\hline & & a43.7 (25 Feb. 1992); & 41.0 (14 Jan. 1992) \\
\hline Letaba & 47.2 & 45.6 (25 Feb. 1992); & 45.5 (20 Dec. 1989 ) \\
\hline Lower-Sabie & 45.3 & a 45.2 (25 Feb. 1992); & 41.5 (27 Oct. 1991) \\
\hline Mopani & 45.0 & a 43.7 (25 Feb. 1992); & 41.3 (14 Jan. 1992) \\
\hline Phalaborwa & 44.6 & 44.3 (25 Feb. 1992); & 43.0 (19 Dec. 1976) \\
\hline Pretoriouskop & 41.5 & 41.2 (15 Oct. 1968); & 41.0 (11 Jan. 1983) \\
\hline Punda Maria & 45.0 & 44.3 (25 Feb. 1992); & 44.0 (20 Dec. 1989) \\
\hline Satara & 45.2 & 45.0 (11 Jan. 1986): & 44.5 (25 Feb. 1992) \\
\hline Shimuwini & 46.0 & a 44.8 (25 Feb. 1992); & 41.3 (14 Jan. 1992) \\
\hline Shingwedzi & b48.0 & 46.5 (25 Feb. 1992); & 46.2 (4 Jan. 1968) \\
\hline Sirheni & 46.7 & a 44.7 (25 Feb. 1992); & 42.4 (17 Jan. 1992) \\
\hline Skukuza & 45.6 & 44.2 (25 Feb. 1992); & 43.6 (12 Oct. 1979) \\
\hline Talamati & 44.8 & a4.3 (25 Feb. 1992); & 41.3 (20 Nov. 1991) \\
\hline
\end{tabular}

a New stations, less than three years" data. ${ }^{b}$ Highest temperature on record in the KNP.

1991/92 were higher than the long-term mean daily maximum, the greatest difference being recorded in February 1992, when the mean daily maximum was $36.0{ }^{\circ} \mathrm{C}$ (Table 3 and Fig. 5). This was also the hottest month, both in terms of highest daily maximum temperatures, and in terms of the number of days with maximum temperatures above $35^{\circ} \mathrm{C}$. Shingwedzi recorded the greatest number of days above $35^{\circ} \mathrm{C}$, with 104 days in the $35.1-40{ }^{\circ} \mathrm{C} ; 15$ days in the $40.1-45.0^{\circ} \mathrm{C}$; and 2 days in the $45.1-50.0^{\circ} \mathrm{C}$ classes.

The highest maximum temperatures ever recorded in the KNP were also recorded in February 1992, and without exception, all on the same day (26). These new records, together with the previous highest records, are given in Table 4. It will be noted from Table 4 that with the exception of Pretoriuskop and Satara, new (but shortlived) records were established on the previous day, only to be broken on the following day. The maximum temperature of $48.0^{\circ} \mathrm{C}$ recorded at Shingwedzi is now also the highest temperature ever recorded in the KNP.

Except for July, August and September, differences between mean daily maximum temperatures during 1991/92 differed significantly from the long-term means for all the other months (Table 3). The mean maximum temperature between 1991/92 and the long-term mean annual maximum differed significantly $(\mathrm{P}=0.0011)$ by $1.6^{\circ} \mathrm{C}$.

A shift in the total number of days per maximum temperature class is clearly evident from Table 5 and Fig. 6, with the total number of days with a maximum temperature of up to and including $30{ }^{\circ} \mathrm{C}$ declining in comparison with the long-term means, and increasing in the remaining four classes. Changes were however found to be statistically significant only in the $20.1-25.0{ }^{\circ} \mathrm{C}$ and $30.1-35.0^{\circ} \mathrm{C}$ classes. The greatest proportion (34.8\% or 127.1 days) of an average year has maximum temperatures of 25.1$30.0^{\circ} \mathrm{C}$. In $1991 / 92$ however, the greatest proportion of the year (36.2\% or 132.3 days) 


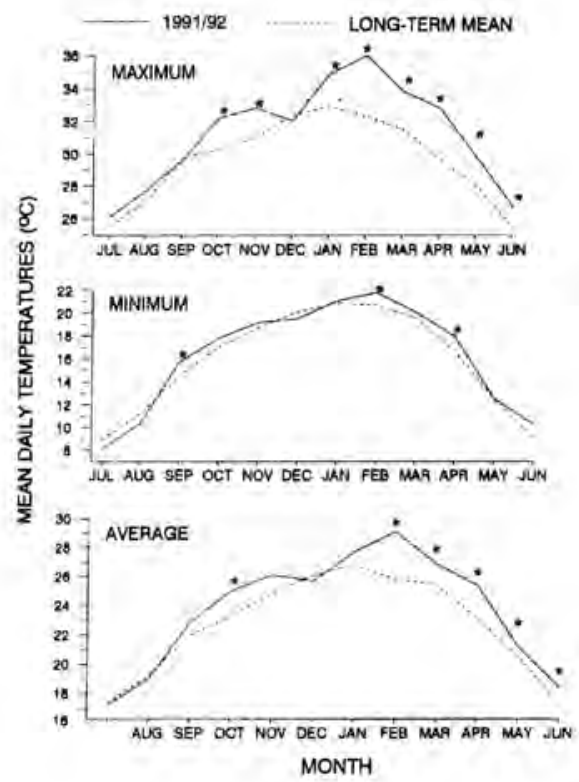

Fig. 5. Mean daily maximum (top), minimum (centre) and average temperatures (bottom) during 1991/92. compared with long-term monthly means. Statistically significant differences are marked with an asterisk. shifted to the $30.1-35.0^{\circ} \mathrm{C}$ range class.

Although monthly daily minimum temperatures during 1991/92 were higher than the long-term monthly means during a total of nine months, differences were only statistically significant in September, February and April. The overall difference was an increase of $0.6{ }^{\circ} \mathrm{C}$ during the year (Table 3 and Fig. 5).

As for maximum temperatures, a shift in the number of days per minimum temperature class is evident, with the number of days up to and including a temperature of $20.0^{\circ} \mathrm{C}$ declining, and increasing in the $20.1-25.0^{\circ} \mathrm{C}$ and $25.1-30.0^{\circ} \mathrm{C}$ classes (Table 5 and Fig. 6). It is interesting to note though that in spite of the general tendency for tempera-

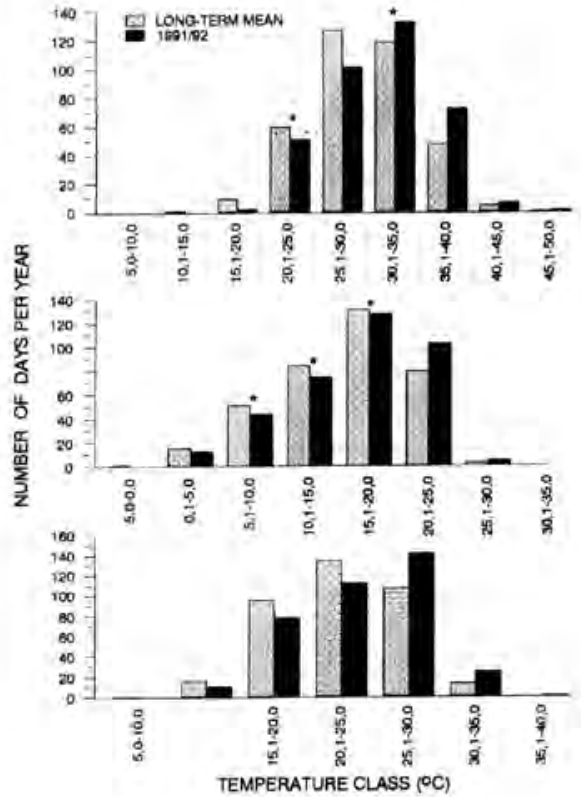

Fig. 6. Mean total number of days during 1991/92 compared with long-term means in maximum (top), minimum (centre) and average temperature classes (bottom). Statistically significant differences arc marked with an asterisk.

tures to increase, both in extreme terms and in the number of days within specific temperature range classes, no minimum temperatures within the $30.1-35.0{ }^{\circ} \mathrm{C}$ range occurred during 1991/92, though days with minimum temperatures in this range have been recorded in previous years. On average, most of the year (35.9\% or 131.2 days) in the KNP has minimum temperatures of 15.1-20.0 ${ }^{\circ} \mathrm{C}$. This decreased only slightly in $1991 / 92$, to $34.9 \%$ ( 127.2 days), though the number of days in the $20.1-25.0^{\circ} \mathrm{C}$ class increased from a mean of 79.5 days $(21.8 \%$ of the year) to a mean of 102.4 days $(28.1 \%)$ in 1991/92.

Average temperatures during 1991/92 differed significantly from the long-term means during October, February, March, 
Table 5

Long-term mean mumber of days per year. and mean totals during 199 I/92 in maximum. minimum and average temperature classes. Statistically significant differences are marked with an asterisk

\begin{tabular}{|c|c|c|c|}
\hline \multicolumn{4}{|c|}{ Number of days in maximum temperature range class } \\
\hline Range & Long-term Mean & $1991 / 92$ & Difference \\
\hline $5.0-10.0$ & 0.01 & 0.00 & 0.01 \\
\hline $10.1-15.0$ & 0.57 & 0.00 & 0.57 \\
\hline $15,1-20.0$ & 8.29 & 1.66 & 6.63 \\
\hline $20.1-25.0$ & 59.14 & 50.94 & $* 8.20(\mathrm{P}=0.047)$ \\
\hline $25,1-30,0$ & 127.10 & 101.17 & 25.93 \\
\hline $30,1-35.0$ & 118.48 & 132.50 & $* 13.77(\mathrm{P}=0.035)$ \\
\hline $35.1 \cdot 40.0$ & 47.35 & 72.32 & 24.97 \\
\hline $40.1-45.0$ & 3.99 & 5.82 & 1.83 \\
\hline $45.1-50.0$ & 0.08 & 0.84 & 0.76 \\
\hline \multicolumn{4}{|c|}{ Number of days in minimum temperature range class } \\
\hline$-5.0-0.0$ & 0.99 & 0.49 & 0.50 \\
\hline $0.1-5.0$ & 15.63 & 12.18 & 3.45 \\
\hline $5.1-10.0$ & 51.31 & 43.87 & $\approx 7.44(\mathrm{P}=0.050)$ \\
\hline $10.1-15.0$ & 84.06 & 74.56 & $\approx 9.50(P=0.038)$ \\
\hline $15.1-20.0$ & 131.15 & 127,21 & $* 3.94(\mathrm{P}=0.010)$ \\
\hline $20.1-25.0$ & 79.46 & 102.39 & 22.93 \\
\hline $25.1-30.0$ & 2.39 & 4.38 & 1.99 \\
\hline $30.1-35,0$ & 0.01 & 0.00 & 0.01 \\
\hline \multicolumn{4}{|c|}{ Number of days in average temperature range class } \\
\hline $5.0-10.0$ & 0.17 & 0.00 & 0.17 \\
\hline 10. $1-15.0$ & 15.68 & 9.72 & 5.96 \\
\hline $15+1-20.0$ & 95.26 & 77,33 & 17.93 \\
\hline $20.1-25.0$ & 134.47 & 112.05 & 22.42 \\
\hline $25.1-30.0$ & 106.48 & 141.34 & 34.86 \\
\hline $30.1-35.0$ & 12.89 & 24,04 & 11.15 \\
\hline $35.1-40.0$ & 0.05 & 0,52 & 0.47 \\
\hline
\end{tabular}

April, May and June (Table 3 and Fig. 5). This is primarily due to the significantly greater daily maximum temperatures during these months, with mean daily minimum temperatures differing significantly only during February and April. For the year as a whole, the average temperature was insignificantly greater than the long-term mean by $1.3{ }^{\circ} \mathrm{C}$.

The number of days up to and including an average temperature of $25.0^{\circ} \mathrm{C}$ decreased in $1991 / 92$ and increased in the remaining classes up to $40.0^{\circ} \mathrm{C}$. (Table 5 and Fig. 6).
None of the changes in these classes were however found to be statistically significant.

Most of the year ( $36.8 \%$ or 134.5 days) has average temperatures between $20.1-25.0{ }^{\circ} \mathrm{C}$. In 1991/92 the greatest proportion of the year ( $38.7 \%$ or 141.3 days) had mean temperatures of $25.1-30.0^{\circ} \mathrm{C}$.

\section{Conclusions}

Although droughts of greater severity have been recorded in localized regions of the KNP in the past, the 1991/92 drought in 
meteorological terms can be regarded as moderately severe over most of the KNP as a whole, It has furthermore proven to be the severest drought in the recorded climatological history of the KNP, with an average of $44.1 \%$ of the long-term MAR having being received. Ecologically however, it had a very severe influence on many organisms.

The most severely effected areas were the Lower-Sabie and Pafuri regions, with the least severely effected areas being the Crocodile Bridge-Malelane areas.

The primary reasons for the severity of the 1991/92 drought were a very significant decline in the number of days on which rain occurred (decreasing by almost $50 \%$ ), and an increase in temperatures.

Two-thirds of the year experienced maximum temperatures of a significantly higher intensity than normal. This, together with slightly increased minimum temperatures and a significant increase in the number of days with daily maximum temperatures greater than $30^{\circ} \mathrm{C}$, resulted in a hotter than normal year.

Although not investigated, these events in combination undoubtedly resulted in a drastic decline in soil moisture and a lowered water table. This is reflected by the death of a diversity of woody plant species, and by changes in the composition of the herbaceous layer, in areas being very important.

\section{Acknowledgements}

The efforts of many weather and rainfall observers in the Kruger National Park and over many years represent the backbone of the Park's climate monitoring programme and therefore deserve recognition.

Mr J.A. Koch (Weather Bureau, Department of Environmental Affairs and Tourism) is thanked for his advice with the treatment of missing data.

\section{References}

ERassius.J.F. 1991. Methodologios for drought monitoring using meteorological duta. PhD thesis. Untversity of the Orange Free State, Bloemfontein.

GIRTEXBACH. W.P.D. 1980, Rainfall patterns in the Kruger National Park Koedoe 23: 35-43.

HuLE. D. 1971. Soil water: Phusical principles and processes. Lst ed. Academic Press, New York.

Hounam, C.E. J.J. Burgos, M.S. Kalik, W. C. PAlmer AND J. RODDA, 1975. Drought and agriculture. WMO Technical Note No. 138. World Meteorological Organization, Geneva.

Intera TYdac 1993. Spans Map User's Guide. Intera Tydac Technologies Inc, USA.

LAING. M. 1992. Comparisons between 1991/92 and the 1982/83 drought. Weather Bureau Newslenter. December: Weather Bureau, Deparment of Envirenmental Affairs, Pretoria.

LYNCH. S.D. AND M.C. DENT. 1990. Appropriate record lengths for the estimation of mean annual and mean monthly precipitation in southern Africa. Water SA 16(2): 93-98.

Manuastics 1993. Statgruphics Plus. Reference and Examples Mamuals. Statistical Graphics Corporation. Cambridge, MA.

PIEna.ar, U. de V. 1985. Indications of progressive desiccation of the Transvaal Lowveld over the past 100 years, and implications for the water stabilization programme in the Kruger National Park. Koedoe 28: 93-165.

Trson, P.D. 1986. Climatic change and variability in southern Africa Oxford University Press. Cape Town.

VoGjFI., C. 1994. (Mis)management of droughts in South Africa: past, present and future. South African Jeurnal of Science 90: 4-6.

Wenther Bureav, 1965. Climate of South Africa. Part 8, General Survey: W.B. 28. Pretoria: Depurtment of Transport.

Weather Bureau. 1988. Climate of Solth Africa. Climate statistics up to 1984. WB 40. Weather Bureau, Department of Environmental Affairs. Pretoria.

WILhte. D.A. AND M.H. GlanT/. 1985. Under standing the drought phenomenon: the role of definitions. Water lnternational 10: 111-120.

World Meteorological, Organization, 1983. Guide to climatological practices. 2 nd ed. WMO No.100. Geneva, Switzerland.

ZaMBATIS, N, 1994. Ferns and flowering plants of Klaserie Private Nature Reserve, eastern Transvaal: an annotated checklist. Bothalia 24(1): 37-53. 